\title{
EFFECTIVE EXTENSION PROGRAMS FOR WOODLOT OWNERS
}

\author{
By J. TORUNSKI ${ }^{1}$
}

Over the past years considerable emphasis has been directed towards the physical improvement of small woodlots. However, relatively little emphasis has been given to the economic, social and extension problems involved. These three problems-economic, social and extension-are often more important and more difficult to solve than the physical problem in an effective extension program for woodlot owners.

It is almost impossible to find one extension program for woodlot owners which will be effective in all of Canada, within all of one province, or even one small community. A multitude of local conditions will dictate individual programs.

To properly understand our program, a brief background of New Brunswick conditions is essential.

Eighty percent of New Brunswick is forested, and of this amount, $50 \%$ is privately owned. We are blessed with reasonably fast growth, good accessibility and in some areas good markets. Turning to the N.B. farm woodlot we find that the average size of woodlot attached to the farm property is 117 acres. In addition, some $45 \%$ of farm woodlot owners own more than one woodlot. It is estimated that the average woodland holdings per farmer is approximately 200 acres, making it quite an economic unit to operate. Practically all N.B. farmers are dependent on their woodlots for part of their cash income. In several areas of N.B. farmers count on their woodlots for the major part of their cash income. The importance of the farm woodlot in N.B. can easily be seen in the following statistics:

Farm Cash Income from sale of woodlot products for 1961-

$$
\text { -average per farmer in Canada }
$$

-average per farmer in N.B.

In addition to the farm woodlot owner just described, we also have many woodlot owners who are $100 \%$ dependent on their woodlots for a living, and there are some investment type woodlot owners.

All forest extension work in New Brunswick is carried out by the Forest Extension Service. This service incorporates extension foresters from the University of New Brunswick, the N.B. Department of Agriculture, and the Canadian Forestry Association of New Brunswick, all working out of one office and one set of files. All work is carried on under the guidance of an able and dedicated Advisory Committee, made up of representatives of agencies interested in Forest Extension work. This situation is unique in Canada and has proven to be the most vital key in our successful extension program.

${ }^{1}$ Extension Forester, New Brunswick Dept, of Agriculture, Fredericton, N.B. 
There are two basic methods generally used in woodlot extension work, and for lack of better terms I will refer to these as the indirect approach and the direct approach. The indirect approach consists of such methods as field days, short courses, study groups, newspaper, radio and T.V. articles, general promotional publicity, etc. The direct approach consists of working directly with individual owners.

In New Brunswick we have concentrated on the direct approach, sometimes referred to as "grassroots forestry". After receiving an application for management assistance from an owner the general procedure taken is as follows:

1) A 1 inch $=5$ chain photo enlargement of the property is procured. We are extremely fortunate in having an excellent provincial photo library with enlarging services.

2) The woodlands are then inspected with the owner. During this visit general management problems, forestry and operating techniques and how the woodlands fit into the owner's enterprise are among the items discussed.

3) A brief, simple management plan for the woodlands is prepared using the photo enlargement and a transparent paper overlay as a base map.

4) The management plan is discussed with the owner and a return trip to the woodlot is usually taken. Generally on this trip we concentrate on the recommended first cutting area. Assistance with tree marking or road location is often given.

5) Woodlot owners are then revisited about once a year to check on progress, additional problems, etc.

There are several general comments which should be made concerning our program.

All owners must apply to the Forest Extension Service for assistance. If an owner takes the time to write a letter he is usually genuinely interested. It is with these interested people that results can be obtained, and this interest has very often rubbed off on his neighbours.

In New Brunswick this woodlot management assistance is incorporated directly into our Tree Farm Program; in fact this is what the program is known as. This service feature gives the Tree Farm Program some meaning. Woodlots which do not qualify as Certified Tree Farms are held in the "Under Management" category of the program. This "Under Management" category has proven very successful in our Tree Farm Program.

The running of property lines or the cruising of woodlots is not part of our service.

Management plans are always "tailor-made" to each owner's situation, taking into account not only forestry problems but also social and economic problems. They are written in simple language. All plans are kept on a sound economic footing. For the first few years the emphasis is usually on reducing the operating costs, better production, and better marketing practices. Then, once the owner sees that he is making good profit, a certain amount of basic silviculture is discussed with the owner. Their enthusiasm for doing a little basic silviculture always amazes us. 
In connection with the management plan the emphasis is always on making the most of what an owner has. In certain stands, clear cutting may be recommended; in others some form of selective cut. In young fir stands the development of quality Christmas trees is encouraged. There are all sorts of combinations which must be considered.

Annual revisits to the owners have proven to be a vital key in our successful program. Their enthusiasm during these visits cannot be described.

What have been our results? In 1957 we started with 27 applications covering 8,100 acres. As of January 1, 1963, we had 126 Tree Farms, 270 lots "Under Management", and 96 applications. The total acreage involved is in excess of 100,000 acres; all this with a minimum of publicity.

Our records show many woodlots producing in excess of one-half cord per acre per year, and the average cash return per acre for the years 1961 and 1962 was $\$ 11.10$.

I have attempted to outline briefly our Tree Farm Program. What are some of the problems we are faced with, and how can improved technology assist in solving these problems?

1. Many owners don't know their own woodlots. The 1 inch $=5$ chain photographs have been of tremendous value in partially solving this problem. Leg work must do the rest.

2. Marketing is a problem in many areas. Although we have found that many woodlot owners do not know what markets exist in their own areas, and often follow poor marketing practices, improved technology may assist in opening up new markets for many species.

3. Improved technology will always be of great assistance in economizing logging operations.

4. However, the two biggest problems, that of family tradition and the social problem, will not be completely solved by improved technology. These two problems must be solved by a careful study and understanding of PEOPLE. Extension programs must consider not only the physical aspect of the woodlot but also the human resource involved. 